\title{
THE CENTRAL EUROPEAN DIET AS AN ALTERNATIVE TO THE MEDITERRANEAN DIET IN ATHEROSCLEROSIS PREVENTION IN POSTMENOPAUSAL OBESE WOMEN WITH A HIGH RISK OF METABOLIC SYNDROME - A RANDOMIZED NUTRITIONAL TRIAL
}

\author{
Monika Duś-Żuchowska1, Joanna Bajerska², Patrycja Krzyżanowska, \\ Agata Chmurzyńska², Anna Miśkiewicz-Chotnicka', Agata Muzsik², \\ Jarosław Walkowiak ${ }^{1 凶}$ \\ 1Department of Pediatric Gastroenterology and Metabolic Diseases, Poznań University of Medical Sciences \\ Szpitalna 27/33, 60-572 Poznań, Poland \\ ${ }^{2}$ Institute of Human Nutrition and Dietetics, Poznań University of Life Sciences \\ Wojska Polskiego 31, 60-624 Poznań, Poland
}

\begin{abstract}
Background. Metabolic syndrome (MS) is a powerful risk factor for atherosclerosis (AT). The crucial method of minimizing the development of atherosclerosis and its clinical manifestations is lifestyle modifications, including following a healthy diet. The aim of the study was to check if the Central European Diet (CED) could be an alternative to the Mediterranean Diet (MED) in the prevention of AT in patients with a risk of MS. Methods. The randomized, single-blind nutritional trial involved 144 obese women with a risk of MS. The subjects were randomly assigned to two groups and followed MED $(n=72)$ or CED $(n=72)$ for 16 weeks. The concentrations of high-sensitivity $\mathrm{C}$-reactive protein (hs-CRP) and asymmetrical dimethylarginine (ADMA) were measured before and after nutritional intervention.

Results. In both studied groups, the concentrations of hs-CRP decreased significantly after the nutritional intervention (CED: $p=0.0107$; MED: $p=0.0002$ ). The ADMA levels were significantly lower after nutritional intervention in the CED group ( $p=0.0187)$ but not in the MED group $(p=0.8354)$. However, the observed changes of hs-CRP concentrations ( $\triangle \mathrm{hs}-\mathrm{CRP})$ and ADMA levels ( $\triangle \mathrm{ADMA})$ were not different between the groups ( $p=0.5307$ and $p=0.0905$, respectively).

Conclusion. In the Central European post-menopausal obese population, a well-designed, energy-restricted diet with the use of food items traditional for the region (CED) could be a good alternative to MED in terms of AT prevention.
\end{abstract}

Keywords: metabolic syndrome, Mediterranean diet, Central European diet, atherosclerosis, hs-CRP, ADMA

\footnotetext{
The study was partly financed by a National Science Centre award based on decision number DEC-2013/09/B/NZ9/02365 and Poznan University od Medical Sciences, Poland.
} 

women with a high risk of metabolic syndrome - a randomized nutritional trial. Acta Sci. Pol. Technol. Aliment., 17(4), $399-407$. http://dx.doi.org/10.17306/J.AFS.2018.0593

\section{INTRODUCTION}

For decades, atherosclerosis (AT), with its life-threatening clinical manifestations, particularly cardiovascular disease and stroke, has been one of the main causes of death amongst the western population. One of the strongest risk factors of AT is the epidemic of obesity (Fruchart et al., 2004). The compilation of risk factors for atherosclerotic cardiovascular disease and type two diabetes, commonly occurring in obese people is called metabolic syndrome (MS) (Grundy, 2016; 2007; Lam and LeRoith, 2000). The predisposition to the development of atherosclerosis in MS is associated with the following risk factors: atherogenic dyslipidemia, elevated blood pressure, prothrombotic and pro-inflammatory state, hyperglycemia and insulin resistance (Grundy, 2016; 2007).

Metabolic syndrome increases the risk of diabetes fivefold and doubles the risk of atherosclerotic cardiovascular disease (Grundy, 2005; 2016). The prevalence of MS ranges from $10 \%$ to $40 \%$ and depends on the population studied and definitions used (Cornier et al., 2008; Grundy, 2016; Lam and LeRoith, 2000). In the Polish population, the incidence of MS diagnosed on the basis of criteria from the International Diabetes Federation (IDF) was almost 30-40\% (Janszky et al., 2011; Pacholczyk et al., 2008). Among them, the postmenopausal women constitute a significant group due to a higher risk of MS (Lobo, 2008; Stachowiak et al., 2015).

Although pharmacological interventions bring benefits to the therapy of co-existing disorders of lipid metabolism, glucose tolerance and hypertension, the paramount elements of treatment are lifestyle modifications including dietary changes, physical activity and weight loss (Lam and LeRoith, 2000; O'Keefe et al., 2008).

The data available from previous research projects suggests that analyzing the overall quality of diet, rather than studying a single food product, helps with the identification of dietary patterns that may reduce cardiovascular risk and prevent the process of atherogenesis (Peñalvo et al., 2016; Petersen et al., 2014; Ros et al., 2014). One of the most popular diet patterns with documented effectiveness, particularly decreased mortality from cardiovascular disease and cancer, is the Mediterranean diet (MED) (Kastorini et al., 2011;
Sofi et al., 2008). Although the large meta-analysis of MED showed beneficial effects on every component of MS, the positive impact on human health was more significant in the populations of the Mediterranean Basin than to populations of different regions of the world (Kastorini et al., 2011). At the same time, the dietary cluster specific to the region of Central Europe is rich in many valuable food items decreasing the risk of AT development. Therefore, the aim of the study was to check, if the Central European Diet (CED) could be an alternative diet pattern compared to MED in terms of its impact on the concentrations of selected atherosclerosis markers - high sensitivity C-reactive protein (hs-CRP) and asymmetrical dimethylarginine (ADMA).

\section{METHODS}

\section{Characteristics of the study group}

The study included 144 female individuals who met the following inclusion criteria:

- postmenopausal status defined as the absence of menses for at least 1 year

- nonsmoking behavioral pattern

- central obesity (defined as waist circumference $\geq 80 \mathrm{~cm}$ plus at least one other from 2005 IDF criteria of MS).

The exclusion criteria were defined as:

- participation in another weight reduction programme

- reported fluctuations in body weight in the previous 6 months

- using insulin, lipid and glucose lowering, anti-inflammatory or hormone replacement therapy

- diabetes mellitus

- chronic liver or kidney disease

- thyroid disease

- food allergy or intolerance to the key products of MED or CED.

In Figure 1 the flowchart illustrating progression of participants through the study is presented. 269 women were registered for the study. 125 women did not meet the inclusion criteria. The randomization process included 144 participants. The CED group consisted of 72 subjects and 72 women formed the MED group. 


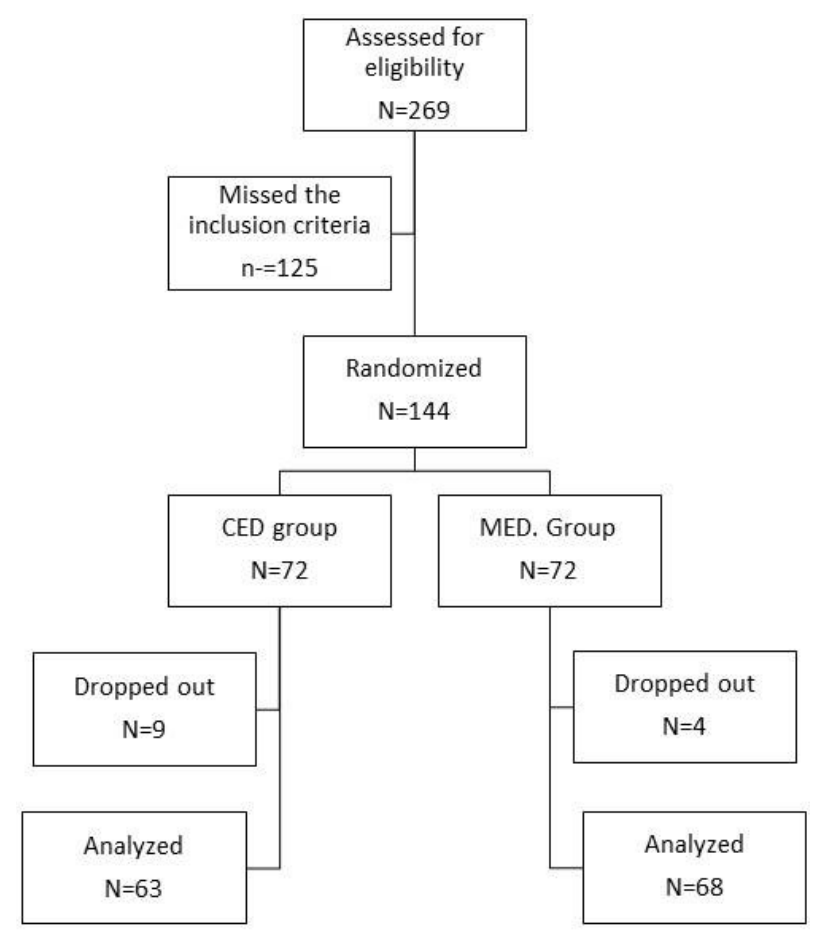

Fig. 1. Flowchart of the trial

The dropouts included 13 subjects who: 1 . had travel or work commitments and missed the final study visit ( 5 women from the CED group and 4 women from the MED group); 2. had cholecystectomy (1 woman from the CED group); 3. had erysipelas (1 woman from the CED group); 4. had family reasons (2 women from the CED group). Anthropometric measurements, in- cluding an evaluation of the body height, weight and body mass index (BMI) of each participant, were conducted upon entry to the study. Baseline characteristics of the study group are presented in Table 1.

\section{Study design}

In this randomized, single blind trial, which has been described in detail by Bajerska et al. (2018), two nutritional interventions, MED and CED, were compared. The food products used in the diets were available in Poland. The volunteers were recruited through advertisements in newspapers. The recruited subjects were checked during a telephone interview if they met the inclusion criteria and then randomly assigned to one of the groups: MED or CED. The randomization process was based on the computer generation of a unique number for each participant. The dietary allocation of the participants was unknown to the investigators (except the dieticians, who were responsible only for diet analysis) until the data collection and analysis had been completed. This report is part of a greater study financed by the National Science Centre (decision number DEC-2013/09/B/NZ9/02365). The nutritional intervention lasted 16 weeks. Both hypocaloric (a 700-kcal per day deficit in comparison to individual energy requirements) diets were balanced according to recommendations found in Table 2. As CED is stereotypically associated with a diet rich in saturated fatty acids and products with a high glycemic index, it is important to point out that the CED model used in the study was based on

Table 1. Baseline characteristics of the study group

\begin{tabular}{|c|c|c|c|c|c|}
\hline & \multicolumn{2}{|c|}{ CED group $(n=72)$} & \multicolumn{2}{|c|}{ MED group $(n=72)$} & \multirow[b]{2}{*}{$p$-value } \\
\hline & $\begin{array}{c}\text { median } \\
\left(1^{\text {st }}-3^{\text {rd }} \text { quartile }\right)\end{array}$ & mean $\pm \mathrm{SD}$ & $\begin{array}{c}\text { median } \\
\left(1^{\left.\text {st }-3^{\text {rd }} \text { quartile }\right)}\right)\end{array}$ & mean $\pm \mathrm{SD}$ & \\
\hline Age, years & $\begin{array}{c}61.00 \\
(57.80-64.00)\end{array}$ & $60.80 \pm 4.70$ & $\begin{array}{c}60.00 \\
(56.80-64.00)\end{array}$ & $60.30 \pm 4.70$ & $\mathrm{~ns}$ \\
\hline BMI, $\mathrm{kg} / \mathrm{m}^{2}$ & $\begin{array}{c}32.95 \\
(30.28-36.58)\end{array}$ & $33.59 \pm 4.16$ & $\begin{array}{c}32.83 \\
(30.38-35.75)\end{array}$ & $33.84 \pm 5.57$ & $\mathrm{~ns}$ \\
\hline $\mathrm{CRP}, \mathrm{mg} / \mathrm{L}$ & $\begin{array}{c}3.1 \\
(1.3-5.9)\end{array}$ & $4.6 \pm 4.4$ & $\begin{array}{c}2.9 \\
(1.3-6.0)\end{array}$ & $4.4 \pm 4.4$ & $\mathrm{~ns}$ \\
\hline $\mathrm{ADMA}, \mathrm{nmol} / \mathrm{ml}$ & $\begin{array}{c}1.01 \\
(0.59-2.75)\end{array}$ & $1.71 \pm 1.49$ & $\begin{array}{c}1.14 \\
(0.71-2.83)\end{array}$ & $1.73 \pm 1.25$ & $\mathrm{~ns}$ \\
\hline
\end{tabular}


Duś-Żuchowska, M., Bajerska, J., Krzyżanowska, P., Chmurzyńska, A., Miśkiewicz-Chotnicka, A., Muzsik, A., Walkowiak, J. (2018). The Central European diet as an alternative to the Mediterranean diet in atherosclerosis prevention in postmenopausal obese women with a high risk of metabolic syndrome - a randomized nutritional trial. Acta Sci. Pol. Technol. Aliment., 17(4), 399-407. http://dx.doi.org/10.17306/J.AFS.2018.0593

Table 2. The characteristics of the diets - the content of main substrates (Bajerska et al., 2018)

\begin{tabular}{|c|c|c|}
\hline Substrate & The amount in CED & The amount in MED \\
\hline Carbohydrates & $55 \%$ of total energy intake & $45 \%$ of total energy intake \\
\hline Protein & $18 \%$ of total energy intake & $18 \%$ of total energy intake \\
\hline $\begin{array}{l}\text { Fat } \\
\text { - } \text { saturated fatty acids (SFAs) } \\
\text { - } \text { monounsaturated fatty acids (MUFAs) } \\
\text { polyunsaturated fatty acids (PUFAs) }\end{array}$ & $\begin{array}{l}27 \% \text { of total energy intake } \\
\text { - } 8 \% \\
\text { - } 10 \% \\
\text { - } 9 \%\end{array}$ & $\begin{array}{l}37 \% \text { of total energy intake } \\
\text { - } 8 \% \\
\text { - } 20 \% \\
\text { - } 9 \%\end{array}$ \\
\hline Others & $\begin{array}{l}\text { high level of dietary fiber from typical } \\
\text { food items in Central Europe (cereals, } \\
\text { pulses, vegetables, fruits) }\end{array}$ & $\begin{array}{l}\text { olive oil used in } 3 \text { of } 4 \text { meals } \\
4 \text { nuts served once a day }\end{array}$ \\
\hline
\end{tabular}

the recommendations of healthy nutrition, including selected products with pro-health properties but consumed traditionally in this region, eg. fish (herring), whole grain rye (eaten as rye bread), oats (eaten as oatmeal), barley (eaten as a cereal grain), root vegetables (beetroot), cabbages, berries, apples, and plums. A set of standardized 2-week menus were prepared for each nutritional intervention using the "Dietetyk" computer program (Jumar, Poznań, Poland), containing a nutrient database of 932 available food items and dishes (Kunachowicz et al., 2005). According to data based on previous studies indicating a reduction of the overall number of food items at home and a decrease in high-fat food choices when a home-delivery service was employed (Gorin et al., 2007), each participant of this study received pre-portioned main meals (covering about $35 \%$ of the daily caloric demand) prepared and delivered by a professional fooddelivery service (Passion Lukasz Bakowski, Poznań, Poland) for the whole period of the nutritional intervention. Other meals were prepared by the participants themselves, according to prescribed dietary recommendations. During the nutritional intervention the study participants reported all the consumed food in a daily compliance questionnaire, which was monitored by the dietician.

The study protocol remained in compliance with the guidelines laid out in the Declaration of Helsinki and was approved by the local Bioethics Committee of the Institutional Review Board at the Poznan University of Medical Sciences, Poland (approval number $582 / 14$ and 603/14). Written informed consent was obtained from each participant.
The trial was registered in the German Clinical Trials Register (DRKS-ID: DRKS00012958; URL: https://www.germanctr.de/).

\section{Biochemical analysis}

After an overnight fast the sample of venous blood was collected, immediately centrifuged and frozen at $-70^{\circ} \mathrm{C}$ until analysis. The concentrations of hs-CRP and ADMA were measured by enzyme-linked immunosorbent assay (ELISA) kits (Human asymmetrical dimethylarginine (ADMA) - SunRed Biological Technology, Shanghai; C-reactive protein - DRG International Inc., New Jersey, USA) at the entry to the study and after 16 weeks in all study participants.

\section{Statistics}

The results are presented as means \pm standard deviations (SD) and medians with interquartile ranges. Statistical analysis was performed with the STATISTICA 12 software (StatSoft Inc., Tulsa, USA). Mann-Whitney U-test was used for the analysis of changes in hsCRP and ADMA levels between the groups (MED vs. CED). Within-group analyses (baseline vs. 16 weeks) were made with the use of the Wilcoxon-rank test. The significance level was set at $p<0.05$.

\section{RESULTS}

\section{hs-CRP}

The hs-CRP concentrations were significantly lower after nutritional intervention in both groups (Table 3). However, the changes in the hs-CRP concentration 
Duś-Żuchowska, M., Bajerska, J., Krzyżanowska, P., Chmurzyńska, A., Miśkiewicz-Chotnicka, A., Muzsik, A., Walkowiak, J. (2018). The Central European diet as an alternative to the Mediterranean diet in atherosclerosis prevention in postmenopausal obese women with a high risk of metabolic syndrome - a randomized nutritional trial. Acta Sci. Pol. Technol. Aliment., 17(4), $399-407$. http://dx.doi.org/10.17306/J.AFS.2018.0593

Table 3. The values of the hs-CRP for CED and MED group before (pre) and after nutritional intervention (post), mg/L

\begin{tabular}{|c|c|c|c|c|c|}
\hline & \multicolumn{2}{|c|}{ CED $(n=63)$} & \multicolumn{2}{|c|}{$\operatorname{MED}(n=68)$} & \multirow[b]{2}{*}{$p$-value } \\
\hline & $\begin{array}{c}\text { median } \\
\left(1^{\text {st }} \text { quartile }-3^{\text {rd }} \text { quartile }\right)\end{array}$ & mean \pm SD & $\begin{array}{c}\text { median } \\
\left(1^{\text {st }} \text { quartile }-3^{\text {rd }}\right. \\
\text { quartile })\end{array}$ & mean $\pm \mathrm{SD}$ & \\
\hline pre & $\begin{array}{c}3.1 \\
(1.2-6.0)\end{array}$ & $4.5 \pm 4.4$ & $\begin{array}{c}2.7 \\
(1.3-6.0)\end{array}$ & $4.5 \pm 4.5$ & 0.7386 \\
\hline post & $\begin{array}{c}2.2 \\
(1.1-4.5)\end{array}$ & $3.6 \pm 3.8$ & $\begin{array}{c}1.6 \\
(0.8-3.8)\end{array}$ & $3.2 \pm 3.6$ & 0.4307 \\
\hline$p$-value & \multicolumn{2}{|c|}{0.0107} & \multicolumn{2}{|c|}{0.0002} & \\
\hline
\end{tabular}

Table 4. The values of $\triangle \mathrm{hs}-\mathrm{CRP}$ in the CED and MED group

\begin{tabular}{|c|c|c|c|}
\hline & \multicolumn{2}{|c|}{$\Delta \mathrm{hs}-\mathrm{CRP}$} & \multirow{2}{*}{$p$-value } \\
\hline & CED & MED & \\
\hline $\begin{array}{l}\text { Median } \\
\left(1^{\text {st }} \text { quartile-}-3^{\text {rd }} \text { quartile }\right)\end{array}$ & $\begin{array}{c}-0.4 \\
([-2.0]-0.2)\end{array}$ & $\begin{array}{c}-0.6 \\
([-2.5]-0.0)\end{array}$ & 0.5307 \\
\hline Mean \pm SD & $-0.9 \pm 3.4$ & $-1.2 \pm 2.9$ & \\
\hline
\end{tabular}

in the MED (Table 5). The changes in ADMA levels ( $\triangle \mathrm{ADMA}$ ) in the CED and MED groups did not differ (Table 6).

The incidence of ADMA reduction was not different between the CED group and the MED group (60.3\% vs. $47.1 \%$, RR 0.7950 , 95\% CI 0.5259 $1.2019, p=0.2766)$.

Table 5. The values of ADMA for the CED and MED group before (pre) and after 16 weeks of nutritional intervention (post), $\mathrm{nmol} / \mathrm{ml}$

\begin{tabular}{|c|c|c|c|c|c|}
\hline & \multicolumn{2}{|c|}{$\operatorname{CED}(n=50)$} & \multicolumn{2}{|c|}{$\operatorname{MED}(n=53)$} & \multirow[b]{2}{*}{$p$-value } \\
\hline & $\begin{array}{c}\text { median } \\
\left(1^{\text {st }} \text { quartile }-3^{\text {rd }} \text { quartile }\right)\end{array}$ & mean \pm sd & $\begin{array}{c}\text { median } \\
\left(1^{\text {st }} \text { quartile }-3^{\text {rd }} \text { quartile }\right)\end{array}$ & mean \pm sd & \\
\hline pre & $\begin{array}{c}1.11 \\
(0.59-2.91)\end{array}$ & $1.74 \pm 1.40$ & $\begin{array}{c}1.14 \\
(0.71-2.81)\end{array}$ & $1.68 \pm 1.18$ & 0.5690 \\
\hline post & $\begin{array}{c}0.93 \\
(0.57-2.64)\end{array}$ & $1.62 \pm 1.33$ & $\begin{array}{c}1.04 \\
(0.75-2.66)\end{array}$ & $1.70 \pm 1.28$ & 0.4723 \\
\hline$p$-value & \multicolumn{2}{|c|}{0.0187} & \multicolumn{2}{|c|}{0.8354} & \\
\hline
\end{tabular}

( $\triangle$ hs-CRP) did not differ between subjects from the CED and MED groups (Table 4).

The incidence of reduction of hs-CRP concentration was not different in subjects in the CED group to those in the MED group (63.5\% vs. $66.2 \%$, RR $1.0794,95 \%$ CI $0.6777-1.7190, p=0.7477)$.

\section{ADMA}

The concentrations of ADMA decreased significantly after nutritional intervention in the CED group but not
Table 6. The values of $\triangle \mathrm{ADMA}$ in the CED and MED group

\begin{tabular}{|c|c|c|c|}
\hline & \multicolumn{2}{|c|}{$\triangle \mathrm{ADMA}$} & \multirow{2}{*}{$p$-value } \\
\hline & CED & MED & \\
\hline $\begin{array}{l}\text { Median } \\
\left(1^{\text {st }} \text { quartile- }\right. \\
\left.3^{\text {rd }} \text { quartile }\right)\end{array}$ & $\begin{array}{c}-0.07 \\
([-0.21]-0.06)\end{array}$ & $\begin{array}{c}0.02 \\
([-0.17]-0.19)\end{array}$ & 0.0905 \\
\hline Mean \pm SD & $-0.12 \pm 0.41$ & $0.02 \pm 0.45$ & \\
\hline
\end{tabular}



women with a high risk of metabolic syndrome - a randomized nutritional trial. Acta Sci. Pol. Technol. Aliment., 17(4), $399-407$. http://dx.doi.org/10.17306/J.AFS.2018.0593

\section{DISCUSSION}

The purpose of this study was to assess if a welldesigned, energy-restricted diet with the use of food items traditional for the region of study participants' origins (CED) could potentially have similar anti-atherogenic effects to MED in postmenopausal women with a high risk of MS. To find out if CED could have beneficial effects similar to MED, we analyzed the concentrations of markers reflecting the endothelial function and inflammatory status (ADMA and hs-CRP, respectively) as the supreme elements involved in the process of plaque formation and, simultaneously, reliable markers of cardiovascular risk (Bălăşoiu et al., 2014; Dus-Zuchowska et al., 2016; Lau et al., 2005).

The strong elements of our study were its randomized, partially-blind character, which minimized the risk of bias, and the high percentage of participants who completed the study $(90.97 \%)$. Due to the common coexistence of many risk factors of AT, like obesity, hypertension and diabetes, it would be difficult to select a large enough group of subjects without the aforementioned disorders to perform a well-designed study (Vogel, 1997). To eliminate potential genderrelated differences we selected female subjects to participate in the study (Vitale et al., 2007). Furthermore, the menopause is considered to be an independent predictor of MS according to predisposition to weight gain, an increase in adipose obesity, a decrease in energy expenditure and adverse disturbances in lipid metabolism after menopausal transition (Lobo, 2008; Polotsky and Polotsky, 2010; Stachowiak et al., 2015). Therefore, our study was limited to postmenopausal women with a high risk of MS as a target group who might benefit most from the nutritional intervention. Although there are many diagnostic criteria for MS, in the study we used 2005 IDF criteria due to their widespread use in Polish medical care.

Since AT is considered to be a chronic low-grade inflammatory condition, some recent research projects were focused on the anti-inflammatory effect of MED (Estruch, 2010; Kastorini et al., 2011). Indeed, oxidative stress and inflammation are the key-events in atherosclerotic plaque formation (Fruchart et al., 2004; Hansson, 2005). There were a few studies documenting the influence of MED on the biomarkers of inflammation related to atherosclerosis. The PREDIMED study showed that, after three months of nutritional intervention, MED reduced serum CRP, IL-6, chemokines, endothelial and monocyte adhesion molecules, whereas the low-fat-diet increased their concentrations (Estruch, 2010). Furthermore, Esposito et al. found that serum concentrations of IL-6, IL-7, IL-18, and hs-CRP decreased significantly in MS subjects in the group receiving MED compared with those receiving a control prudent diet (Esposito et al., 2004). In addition, results from cross-sectional studies in Mediterranean and United States populations confirmed the antiinflammatory properties of MED (Chrysohoou et al., 2004; Fung et al., 2005; Salas-Salvadó et al., 2008). Although all of these studies presented the beneficial impacts of MED on the inflammatory process, our study is the first one comparing the results obtained in the MED group to those in the CED. In our study, we revealed a decrease of hs-CRP in both CED and MED groups. The explanation of this phenomenon may be found in the similar amount of food ingredients with documented anti-inflammatory effects like antioxidants, fiber and omega-3 fatty acids (Estruch, 2010). Although both CED and MED have a positive impact on hs-CRP concentration, for the population of Central Europe, the CED seems to be an easier diet pattern in the prevention of low-grade inflammatory disorders like AT, due to better accessibility to, and quality of, regional food products.

The second branch of the study was the assessment of ADMA concentrations as a marker of endothelial function and an independent risk factor for the progression of atherosclerosis and cardiovascular death (Antoniades et al., 2009). An elevated ADMA concentration inhibits endothelial nitric oxide synthase, decreases nitric oxide levels and, in consequence, results in endothelial dysfunction and the activation of chemokines and adhesion molecules (De Gennaro Colonna et al., 2009). To the authors' best knowledge, this is the first study assessing the impact of MED and CED on ADMA concentrations in subjects with a high risk of MS. There were few studies documenting the central role of dietary patterns in improving endothelial function, but the mechanisms of this effect remain unknown (Fuentes et al., 2001; Martínez-González et al., 2016). In the study of Eid et al, the impact of omega-3 polyunsaturated fatty acid supplementation and/or MED in men with a high risk of cardiovascular 

women with a high risk of metabolic syndrome - a randomized nutritional trial. Acta Sci. Pol. Technol. Aliment., 17(4), $399-407$. http://dx.doi.org/10.17306/J.AFS.2018.0593

disease were assessed. In this study, none of the interventions decreased ADMA concentrations (Eid et al., 2006). In our study the ADMA concentration lowered significantly after nutritional intervention in the CED group but not in the MED group. As the amount of polyunsaturated fatty acids in both diets was similar, this discovery may be explained by the metabolic adaptations of the population to a specific diet resulting from many centuries of food traditions (Lovegrove and Gitau, 2008). Indeed, Kastorini et al. (2011) showed the better effects of MED in subjects coming from Mediterranean Basin area. Similarly, the better results of CED in our study may have been caused by the native character of the diet for the subjects with Central European origin.

As the study was based on two hypocaloric diets, the observed effects could be attributed to changes in body weight or visceral fat. Although the women experienced significant $(p<0.001)$ losses (mean $(95 \%$ $\mathrm{CI})$ ): $7.6 \mathrm{~kg}(-8.2,-7.0)$ for body weight and $0.26 \mathrm{~kg}$ $(-0.28,-0.23)$ of visceral fat as compared with baseline, no differences between diets were observed. Similarly, no relationship to dietary intake of omega 6 and omega 3 polyunsaturated fatty acids was observed. However, as mentioned before, in more adherent participants, dietary fiber intake was significantly higher $(p<0.001)$ in CED: $23.2 \mathrm{~g} / 1000 \mathrm{kcal}(22.5$, 23.7) than in MED subjects: $17.2 \mathrm{~g} / 1000 \mathrm{kcal}(16.4$, 18.0; Bajerska et al., 2018). Although there is strong evidence that dietary fiber or food naturally rich in fiber decrease circulating CRP levels in overweight/ obese adults (Jiao et al., 2015), we did not observe any differences in CRP concentrations between diets. On the other hand, we documented a tendency toward decrease of ADMA concentrations. The available data regarding the influence of diet on ADMA levels is scarce. King and DeLegge (2009) did not observe any effect of psyllium fiber on its levels.

The present study is the first one designed to compare the effect of CED and MED on selected atherosclerosis markers in the population of postmenopausal females with a high risk of MS. Although there have been several studies which reported a potential effect of MED on atherosclerosis process, metabolic syndrome and cardiovascular health, none of them have compared it with CED (Holvoet, 2008; Kastorini et al., 2011; Ros et al., 2014).
In conclusion, both diets, MED and CED, had a positive effect on the concentration of hs-CRP and may be useful tools in the prevention of the inflammatory process and hence atherosclerosis. Since the effect on ADMA concentrations was significant in the CED group, the CED diet could be successfully applied in the population of Central Europe to prevent endothelial dysfunction.

As accessibility to the regional food products of CED is higher in Central Europe, the CED seems to be a good alternative to MED in terms of the impact on selected AT biomarkers in this population.

\section{REFERENCES}

Antoniades, Ch., Shirodaria, Ch., Leeson, P., Antonopoulos, A., Warrick, N., Van-Assche, T., ..., Channon, K. M. (2009). Association of plasma asymmetrical dimethylarginine (ADMA) with elevated vascular superoxide production and endothelial nitric oxide synthase uncoupling: Implications for endothelial function in human atherosclerosis. Eur. Heart J., 30(9), 1142-1150. https:// doi.org/10.1093/eurheartj/ehp061

Bajerska, J., Chmurzyńska, A., Muzsik, A., Krzyżanowska, P., Mądry, E., Malinowska, A., Walkowiak, J. (2018). Weight loss and metabolic health effects from energyrestricted Mediterranean and Central-European diets in postmenopausal women: A randomized controlled trial. Sci. Rep., 8. https://doi.org/10.1038/s41598-018-29495-3

Bălăşoiu, M., Bălăşoiu, A. Th., Stepan, A. E., Dinescu, S. N., Avrămescu, C. S., Dumitrescu, D., ..., Alexandru, D. (2014). Proatherogenic adipocytokines levels in metabolic syndrome. Roman. J. Morphol. Embryol., 55(1), 29-33.

Chrysohoou, Ch., Panagiotakos, D. B., Pitsavos, Ch., Das, U. N., Stefanadis, Ch. (2004). Adherence to the Mediterranean diet attenuates inflammation and coagulation process in healthy adults: The Attica study. J. Am. College Cardiol., 44(1), 152-158. https://doi.org/10.1016/j. jacc.2004.03.039

Cornier, M.-A., Dabelea, D., Hernandez, T. L., Lindstrom, R. C., Steig, A. J., Stob, N. R., ..., Eckel, R. H. (2008). The metabolic syndrome. Endocrine Rev., 29(7), 777822. https://doi.org/10.1210/er.2008-0024

De Gennaro Colonna, V., Bianchi, M., Pascale, V., Ferrario, P., Morelli, F., Pascale, W., ..., Turiel, M. (2009). Asymmetric dimethylarginine (ADMA): An endogenous inhibitor of nitric oxide synthase and a novel cardiovascular risk molecule. Med. Sci. Monit. Int. Med. J. Exper. Clin. Res., 15(4), RA91-101. 
Duś-Żuchowska, M., Bajerska, J., Krzyżanowska, P., Chmurzyńska, A., Miśkiewicz-Chotnicka, A., Muzsik, A., Walkowiak, J. (2018). The Central European diet as an alternative to the Mediterranean diet in atherosclerosis prevention in postmenopausal obese women with a high risk of metabolic syndrome - a randomized nutritional trial. Acta Sci. Pol. Technol. Aliment., 17(4), $399-407$. http://dx.doi.org/10.17306/J.AFS.2018.0593

Dus-Zuchowska, M., Madry, E., Krzyzanowska, P., Bogdanski, P., Walkowiak, J. (2016). Twelve-week-conjugated linoleic acid supplementation has no effects on the selected markers of atherosclerosis in obese and overweight women. Food Nutr. Res., 60, 32776.

Eid, Hilde M. A., Arnesen, H., Hjerkinn, E. M., Lyberg, T., Ellingsen, I., Seljeflot, I. (2006). Effect of diet and omega-3 fatty acid intervention on asymmetric dimethylarginine. Nutr. Metab., 3, 4. https://doi. org/10.1186/1743-7075-3-4

Esposito, K., Marfella, R., Ciotola, M., Di Palo, C., Giugliano, F., Giugliano, G., ..., Giugliano, D. (2004). Effect of a Mediterranean-style diet on endothelial dysfunction and markers of vascular inflammation in the metabolic syndrome: A randomized trial. JAMA, 292(12), 1440 1446. https://doi.org/10.1001/jama.292.12.1440

Estruch, R. (2010). Anti-inflammatory effects of the Mediterranean diet: the experience of the PREDIMED study. Proc. Nutr. Soc., 69(3), 333-340. https://doi. org/10.1017/S0029665110001539

Fruchart, J.-Ch., Nierman, M. C., Stroes, E. S. G., Kastelein, J. J. P., Duriez, P. (2004). New risk factors for atherosclerosis and patient risk assessment. Circulation, 109(23, Suppl. 1), III15-19. https://doi.org/10.1161/01. CIR.0000131513.33892.5b

Fuentes, F., López-Miranda, J., Sánchez, E., Sánchez, F., Paez, J., Paz-Rojas, E., ..., Pérez-Jiménez, F. (2001). Mediterranean and low-fat diets improve endothelial function in hypercholesterolemic men. Ann. Intern. Med., 134(12), 1115-1119.

Fung, T. T., McCullough, M. L., Newby, P. K., Manson, J. E., Meigs, J. B., Rifai, N., ..., Hu, F. B. (2005). Dietquality scores and plasma concentrations of markers of inflammation and endothelial dysfunction. Am. J. Clin. Nutr., 82(1), 163-173.

Gorin, A. A., Raynor, H. A., Niemeier, H. M., Wing, R. R. (2007). Home grocery delivery improves the household food environments of behavioral weight loss participants: Results of an 8-week pilot study. Int. J. Behav. Nutr. Phys. Activ., 4, 58. https://doi. org/10.1186/1479-5868-4-58

Grundy, S. M. (2005). Diagnosis and management of the metabolic syndrome: An American Heart Association/ National Heart, Lung, and Blood Institute Scientific Statement. Circulation, 112(17), 2735-2752. https://doi. org/10.1161/CIRCULATIONAHA.105.169404

Grundy, S. M. (2007). Metabolic syndrome: A multiplex cardiovascular risk factor. J. Clin. Endocrinol. Metab., 92(2), 399-404. https://doi.org/10.1210/jc.2006-0513
Grundy, S. M. (2016). Metabolic syndrome update. Trends Cardiovasc. Med., 26(4), 364-373. https://doi. org/10.1016/j.tcm.2015.10.004

Hansson, G. K. (2005). Inflammation, atherosclerosis, and coronary artery disease. New Engl. J. Med., 352(16), 1685-95. https://doi.org/10.1056/NEJMra043430

Holvoet, P. (2008). Relations between metabolic syndrome, oxidative stress and inflammation and cardiovascular disease. Verhandel. - Konink. Acad. Voor Geneesk. Belg., 70(3), 193-219.

Janszky, I., Vatten, L., Romundstad, P., Laugsand, L. E., Bjørngård, J. H., Mańczuk, M., Zatoński, W. A. (2011). Metabolic syndrome in Poland - the PONS study. Ann. Agric. Environ. Med. AAEM, 18(2), 270-272.

Jiao, J., Xu, J.-Y., Zhang, W., Han, S., Qin, L.-Q. (2015). Effect of dietary fiber on circulating C-reactive protein in overweight and obese adults: a meta-analysis of randomized controlled trials. Int. J. Food Sci. Nutr., 66(1), 114119. https://doi.org/10.3109/09637486.2014.959898

Kastorini, Ch.-M., Milionis, H. J., Esposito, K., Giugliano, D., Goudevenos, J. A., Panagiotakos, D. B. (2011). The effect of Mediterranean diet on metabolic syndrome and its components: meta-analysis of 50 studies and 534,906 individuals. J. Am. Coll. Cardiol., 57 (11), 1299-1313. https://doi.org/10.1016/j.jacc.2010.09.073

King, D. E., DeLegge, M. (2009). The impact of fiber supplementation on ADMA levels. Nutr. Clin. Pract., 24(1), 80-83. https://doi.org/10.1177/0884533608329229

Kunachowicz, H., Nadolna, I., Przygoda, B., Iwanow, K. (2005). Tabele składu i wartości odżywczej żywności [Tables of composition and nutritional value of food]. Warszawa: PZWL [in Polish].

Lam, D. W., LeRoith, D. (2000). Metabolic syndrome. In: L. J. de Groot, G. Chrousos, K. Dungan, K. R. Feingold, A. Grossman, J. M. Hershman, ..., A. Vinik (Eds.), Endotext [Internet]. South Dartmouth (MA): MDText.com. https://www.ncbi.nlm.nih.gov/pubmed/25905173

Lau, D. C. W., Dhillon, B., Yan, H., Szmitko, P. E., Verma, S. (2005). Adipokines: molecular links between obesity and atheroslcerosis. Am. J. Phys. Heart Circul. Phys., 288(5), H2031-2041. https://doi.org/10.1152/ ajpheart.01058.2004

Lobo, R. A. (2008). Metabolic syndrome after menopause and the role of hormones. Maturitas, 60(1), 10-18. https://doi.org/10.1016/j.maturitas.2008.02.008

Lovegrove, J. A., Gitau, R. (2008). Nutrigenetics and CVD: What does the future hold? Proc. Nutr. Soc., 67(2), 206213. https://doi.org/10.1017/S0029665108007040

Martínez-González, M. Á., Ruiz-Canela, M., Hruby, A., Liang, L., Trichopoulou, A., Hu, F. B. (2016). Intervention 

women with a high risk of metabolic syndrome - a randomized nutritional trial. Acta Sci. Pol. Technol. Aliment., 17(4), $399-407$. http://dx.doi.org/10.17306/J.AFS.2018.0593

trials with the Mediterranean diet in cardiovascular prevention: Understanding potential mechanisms through metabolomic profiling. J. Nutr., March, https://doi. org/10.3945/jn.115.219147

O’Keefe, J. H., Gheewala, N. M., O’Keefe, J. O. (2008). Dietary strategies for improving post-prandial glucose, lipids, inflammation, and cardiovascular health. J. Am. Coll. Cardiol., 51(3), 249-255. https://doi.org/10.1016/j. jacc.2007.10.016

Pacholczyk, M., Ferenc, T., Kowalski, J. (2008). Zespół metaboliczny. Część II: patogeneza zespołu metabolicznego i jego powikłań [The metabolic syndrome. Part II: Its mechanisms of development and its complications]. Post. Hig. Med. Dośw., 16, 62, 543-558 [in Polish]. https://www.ncbi.nlm.nih.gov/pubmed/18936730

Peñalvo, J. L., Fernández-Friera, L., López-Melgar, B., Uzhova, I., Oliva, B., Fernández-Alvira, J. M., ..., Fuster, V. M. D. (2016). Association between a social-business eating pattern and early asymptomatic atherosclerosis. J. Am. Coll. Cardiol., 68(8), 805-814. https://doi. org/10.1016/j.jacc.2016.05.080

Petersen, K. S., Clifton, P. M., Keogh, J. B. (2014). The association between carotid intima media thickness and individual dietary components and patterns. Nutr. Metab. Cardiovasc. Dis., 24(5), 495-502. https://doi. org/10.1016/j.numecd.2013.10.024

Polotsky, H. N., Polotsky, A. J. (2010). Metabolic implications of menopause. Semin. Reprod. Med., 28(5), 426434. https://doi.org/10.1055/s-0030-1262902
Ros, E., Martinez-Gonzalez, M. A., Estruch, R., Salas-Salvado, J., Fito, M., Martinez, J. A., Corella, D. (2014). Mediterranean diet and cardiovascular health: Teachings of the PREDIMED study. Adv. Nutr. Int. Rev. J., 5(3), 330S-336S. https://doi.org/10.3945/an.113.005389

Salas-Salvadó, J., Garcia-Arellano, A., Estruch, R., Marquez-Sandoval, F., Corella, D., Fiol, M., ..., Ros, E. (2008). Components of the Mediterranean-type food pattern and serum inflammatory markers among patients at high risk for cardiovascular disease. Eur. J. Clin. Nutr., 62(5), 651-659. https://doi.org/10.1038/sj.ejcn.1602762

Sofi, F., Cesari, F., Abbate, R., Gensini, G. F., Casini, A. (2008). Adherence to Mediterranean diet and health status: meta-analysis. BMJ, 337, a1344-a1344. https://doi. org/10.1136/bmj.a1344

Stachowiak, G., Pertyński, T., Pertyńska-Marczewska, M. (2015). Metabolic disorders in menopaus. Menop. Rev., 1, 59-64. https://doi.org/10.5114/pm.2015.50000

Vitale, C., Miceli, M., Rosano, G. M. C. (2007). Genderspecific characteristics of atherosclerosis in menopausal women: risk factors, clinical course and strategies for prevention. Climacteric, 10, sup. 2, 16-20. https://doi. org/10.1080/13697130701602712

Vogel, R. A. 1997. Coronary risk factors, endothelial function, and atherosclerosis: A review. Clin. Cardiol., 20(5), 426-432. 